УДК 378.4

ЛЕЙ СЯО

\title{
ВИЗНАЧЕННЯ ПОНЯТТЯ «КОМПЕТЕНТНІСТЬ КУЛЬТУРНОГО САМОВИРАЖЕННЯ»
}

\author{
(C) Лей Сяо, 2019 \\ https://orcid.org/0000-0003-1750-8567 \\ http://doi.org/10.34142/2312-2471.2019.62.13
}

У статті розглядаються загальні положення визначення компетентності культурного самовираження особистості. Зазначено, щуо дослідження будь-якої компетентності особистості повинно базуватися на компетентнісно-орієнтованій парадигмі освіти, щуо включає формування не лиме теоретичних знань, а й прикладної складової підготовки майбутнього фахівия. Визначено, щзо питання пов'язане з компетентнісним підходом повинен розглядатися у тісному зв'язку з конияепц̧ією «Навчання впродовж усього життя» (Life Long Learning, LLL). Особливо цуе важливо в контексті розгляду ключових компетентностей. Розвиток компетентнісноорієнтованого навчання та навчання впродовж усього життя базується на вирішенні трьох основних проблем: використанні різних підходів $i$ методів навчання; підтрими̧і педагогів та інших працівників освіти; оцінці та діагностиці сформованості компетентності. Констатовано, щуо обізнаність та самовираження у сфері культури розглядається багатьма європейськими вченими як здатність до розуміння творчості у мистецтві, уміння формувати власні мистецькі смаки, самостійно виражати ідеї, досвід та почуття за допомогою мистецььких надбань людства. Змістовим наповненням иієї компетентності є глибоке розуміння своєї національної ідентичності як основи доброзичливого ставлення та поваги до міжкультурного розмаїття та вираження інших людей. Компетентність культурного самовираження передбачає розуміння та повагу щуодо того, як ідеї та значення творчо самовиражаються, передаються в різних культурах через низку видів мистеитва та інших культурних форм. Це передбачає залучення до розуміння, розвитку та висловлення власних ідей $i$ відчуттів. Узагальнення наукового пошуку дозволили визначити компетентність культурного самовираження як складний понятійний конструкт, щуо включає знання, навички та підходи до міжкультурного спілкування на основі розуміння і поваги до оточуючих їх ідей, де самовираження втілюється через різні галузі мистецтвва та культури.

Ключові слова: компетентність, культура, мистецтво, міжкультурне спілкування, освіта, особистість, самовираження. 


\section{Lei Siao. Definition of the Concept "Competence of Cultural Self- Expression»}

The article considers the general requirements for determining the competence of cultural self-expression of an individual. It is noted that the study of any competence of an individual should be based on the competence-oriented paradigm of education, which includes the formation not only theoretical knowledge, but also the applied component of training future professionals. It is determined that the issue of competence approach should be considered in close connection with the concept "Life Long Learning (LLL)". This is especially important in the context of considering key competencies. The development of competency-based learning and lifelong learning is based on solving three main problems: the use of different approaches and methods of learning; support for teachers and other educators; assessment and diagnostics of competence formation. It is stated that awareness and self-expression in the culture field is considered by many European scholars as the ability to understand creativity in art, the ability to form their own artistic tastes, to express ideas, experiences and feelings through the artistic heritage of mankind. The content of this competence is a deep understanding of one's national identity as the basis for a friendly attitude and respect for intercultural diversity and the expression of other people. Competence of cultural self-expression implies understanding and respect for how ideas and meanings are creatively expressed, transmitted in different cultures through a number of arts and other cultural forms. This involves engaging in understanding, developing and expressing one's own ideas and feelings. Generalizations of scientific research allowed defining the competence of cultural self-expression as a complex conceptual construct that includes knowledge, skills and approaches to intercultural communication based on understanding and respect for surrounding ideas, where self-expression is embodied through various arts and culture.

Key words: competence, culture, art, intercultural communication, education, personality, self-expression.

Постановка проблеми. У XXI столітті становлення фахівця складається 3 багатьох факторів, одним 3 яких $\epsilon$ його здатність до самовираження та самопозиціювання у професійній діяльності. Дослідження процесу формування компетентності культурного самовираження, обгрунтування іï наукових засад передбачає вивчення сутності цього складного понятійного утворення, його особливостей та генези.

Процеси глобального міжкультурного обміну в усіх ланках суспільного життя висувають певні умови успішності майбутнього професіонала, до яких відносяться здатність до кроскультурного порозуміння, вміння гармонійно поєднувати командну та індивідуальну професійну діяльність і здатність до самовираження в умовах культурного різноманіття, відтак виникає потреба в подальшому розвитку компетентності культурного самовираження, оскільки 
становлення культури особистості як найважливішої умови іiї самоорганізації та самореалізації є одним із центральних завдань сучасної вищої освіти [1].

Аналіз останніх досліджень і публікацій. На компетентнісноорієнтованій парадигмі, як основі підготовки сучасного фахівця, акцентують свою увагу науковці Ю. Биков, І. Зязюн, О. Малихін, А. Хуторськой, Dong Xiaobo. Процес формування культури та окремі аспекти розвитку компетентності культурної обізнаності та самовираження особистості у вищій школі розглянуто в наукових працях І. Гриценко, І. Зимньої, О. Квітка, Н. Хорошилової, А. Adabaş, Н. Kaygin та інших.

Виділення невирішених раніше частин - це дослідження поняття «компетентність культурного самовираження».

Метою статті с визначення поняття «компетентність культурного самовираження».

Виклад основного матеріалу. Розвиток будь-якого питання, пов'язаного з компетентнісним підходом у наш час повинен розглядатися у тісному зв'язку 3 концепцією «Навчання впродовж усього життя» (Life Long Learning, LLL). Особливо це важливо в контексті розгляду ключових компетентностей. Концепція LLL набуває все більшого значення в процесі цифровізації та трансформації суспільних відносин у всьому світі.

Підвищення ефективності праці та комунікації між суб'єктами трудових відносин сьогодні є найважливішою основою успіху для країн, які хочуть бути конкурентоспроможними на міжнародному рівні [6]. Отже, одним 3 найважливіших завдань консолідованих сил держави, бізнесу та громадян $\epsilon$ розвиток компетентності культурної обізнаності та самовираження особистості в системі ключових компетентностей. Визнання освітою значущості культурного самовираження майбутніх професіоналів $\epsilon$ основою коректної побудови освітнього процесу.

За визначенням I. Коробової, компетентнісно-орієнтована парадигма освіти забезпечує соціально-культурні та особистісно-професійні потреби суспільства в процесі розвитку сучасної освіти. Такий підхід дозволяє зосередити увагу учасників освітнього процесу на практичній складовій навчання та отримати навички реальної роботи [3]. Розвиток компетентнісноорієнтованого навчання i навчання впродовж усього життя базується на вирішенні трьох основних проблем: використанні різних підходів і методів навчання; підтримці педагогів та інших працівників освіти; оцінці та діагностиці сформованості компетентності [7].

Дж. Равен розкриває основні структурні компонентами будь-якої компетентності, а саме: когнітивну, мотиваційно-ціннісну, емоційно-вольову. Окремо Дж. Равен акцентує увагу на навичках та досвіді поведінки в ситуаціях подолання труднощів, що забезпечують впевненість у подальшій професійній діяльності [5].

Особливо цінним для нашого дослідження $є$ аналіз та співставлення понять «соmpetency/competence», проведене А. Проценко. Учений у своєму дисертаційному дослідженні проводить співставлення розуміння поняття 
«компетентності» у різних наукових школах Північної Америки та Західної Європи. За визначенням А. Проценко, в американській освітньо-науковій традиції частіше вживається визначення «соmpetency», що визначає якості або моделі поведінки, за якими оцінюється компетентність особи у процесі праці. У Західно-Свропейській освітньо-науковій традиції, на думку А. Проценко, привалює британський підхід до вживання «competence», тобто вимоги до фахівця, які виокремлюються шляхом аналізу функцій його професійної діяльності. При такому підході моделі компетентностей аналізуються через професійні стандарти, що містять набір ролей для кожної окремої посади [4].

I. Зязюн висловлює важливу думку для більш глибокого розуміння сутності компетентності, де компетентність людини виступає як набута властивість та продукт власної життєвої активності особистості, ініційованої процесом освіти [2]. Визначившись з розумінням поняття «компетентності», розглянемо таке понятійне утворення як «компетентність культурного самовираження».

Обізнаність та самовираження у сфері культури розглядається багатьма європейськими вченими як здатність до розуміння творчості у мистецтві, уміння формувати власні мистецькі смаки, самостійно виражати ідеї, досвід та почуття за допомогою мистецьких надбань людства. Особливістю цієї компетентності є глибоке розуміння своєї національної ідентичності як основи доброзичливого ставлення та поваги до міжкультурного розмаїття та вираження інших людей.

Основними навичками, які притаманні цій компетентності, є здатність виражати та інтерпретувати з емпатією образні та абстрактні ідеї, переживати емоції у різних сферах мистецтва та культури. Крім того, навички, пов’язані 3 компетентністю культурного самовираження, включають здатність визначати i усвідомлювати можливості для особистої, соціальної або комерційної цінності через мистецтво та інші культурні форми, а також здатність брати участь в творчих процесах як індивідуально, так і колективно. Важливим елементом компетентності культурного самовираження $є$ позитивне ставлення та цікавість до світу. Важливо відкрито ставитися до різноманітності форм культурного самовираження і поважати його у собі та оточуючих.

Компетентність культурного самовираження передбачає розуміння та повагу щодо того, як ідеї та значення творчого самовиражаються, передаються в різних культурах через низку видів мистецтва та інших культурних форм. Це передбачає залучення до розуміння, розвитку та висловлення власних ідей та відчуттів.

Відповідно до позиції вчених Європейського Союзу компетентність культурного самовираження включає такі елементи як: знання, навички та підходи, пов'язані з цією компетенцією.

Знання. Знання місцевої, національної, регіональної, європейської та глобальної культури, включаючи різні мови і традиції, вимагає розуміння власної ідентичності та культури, що розвивається. Спадщина у світі 
культурного різноманіття таких як мистецтво та інші культурні форми можуть бути способом як бачити, так і формувати світ.

Навички. Здатність висловлювати та інтерпретувати образні та абстрактні ідеї, здатність це робити в різних культурних та мистецьких формах, усвідомлювати власні можливості для особистого, соціального бізнес-зростання в галузі культури та мистецтва.

Підходи. Повага та відкрите ставлення до різноманітності культурного вираження разом з етичним та відповідальним підходом до інтелектуальної та культурної власності. Позитивне ставлення також включає зацікавленість світом, відкритість до нових можливостей [9].

На думку словенських вчених B. Sicherl-Kafol та G. Denac, існує реальна розбіжність між декларованими принципами існування «суспільства знань» та тим станом освітнього середовища сьогодні, яке дуже слабо інтегрує освіту 3 мистецтвом на практиці, що значно нівелює можливості культурного самовираження здобувачів освіти. Вчені акцентують увагу свого дослідження на можливостях музичної взаємодії у процесі міжкультурного порозуміння та самовираження здобувачів освіти [10].

B. Sicherl-Kafol та G. Denac розкривають роль музичного спілкування у процесі культурного самовираження здобувачів освіти та зазначають, що спільна музична творчість дозволила створити потік інформації між усіма учасниками, одночасно, задовольняючи їх емоційні потреби у безпеці та сприйнятті. Здобувачі освіти мали змогу висловити власні погляди на світ своїм індивідуальним способом за допомогою музики. Музика, як основна мова спілкування, забезпечувала «засіб, за допомогою якого люди можуть ділитися емоціями, намірами та значеннями, навіть якщо їх розмовні мови можуть бути незрозумілими взагалі». Учасники мали можливість слухати одне одного, спілкуватися та співпрацювати, тим самим ділитися своїм досвідом, думками та цінностями [10].

Важливим для дослідження є напрацювання китайського вченого Dong Xiaobo, де вчений аналізує компетентність культурного самовираження на основі міжкультурного спілкування здобувачів освіти у процесі вивчення іноземної мови. Dong Xiaobo робить цікаві висновки, що студенти, які сприймають культуру країни, мову, яку вони вивчають, використовують власні норми поведінки для інтерпретації мислення, поведінки та навіть зовнішнього вигляду іноземців [8]. Набуття компетентності культурного самовираження $\epsilon$ однією з головних цілей викладання іноземних мов.

За визначенням Dong Xiaobo, культурологічна обізнаність - це термін, що використовується для опису чутливості до впливу на культурну поведінку. Для поліпшення міжкультурної комунікації здобувачів освіти та їх самовираження найкращим способом $\epsilon$ занурення їх в іншомовну культурну атмосферу та особистий контакт з носіями мови. Роблячи це, можна не лише отримати певні раціональні знання про іншу культуру, але й засвоїти їі основні догми шляхом перцептивного порівняння з китайською культурою [8]. 
Висновки. Таким чином, можна дійти висновку, що компетентність культурного самовираження - це складний понятійний конструкт, що включає знання, навички та підходи до міжкультурного спілкування на основі розуміння і поваги до оточуючих їх ідей, де самовираження втілюється через різні галузі мистецтва та культури. Таке визначення компетентності культурного самовираження $\epsilon$ перехідним та потребує подальшого змістового наповнення.

Перспективи подальших розвідок. У майбутніх наукових дослідженнях планується розглянути впровадження компетентності культурного самовираження здобувачів освіти у закладах вищої освіти КНР.

\section{Jimepamypa}

1. Дубасенюк О. Загальнокультурна компетентність: сутність та наукові підходи // Формування загальнокультурної компетентності майбутніх фахівців / за ред. О.С. Березюк, О.М. Власенко. Житомир: Вид-во ЖДУ ім. І. Франка, 2013. 5-10.

2. Зязюн І. Філософія педагогічної дії : монографія / І.А. Зязюн. Черкаси : ЧНУ імені Богдана Хмельницького, 2008. 608 с.

3. Коробова I. Компетентнісно орієнтована методична підготовка майбутніх учителів фізики на засадах індивідуального підходу: монографія. Херсон : ФОП Грінь Д. С., 2016. 366 с.

4. Проценко А. Формування професійної компетентності майбутніх учителів фізичної культури у процесі педагогічної практики: дис... канд.. пед.. наук: спец. 13.00.04 «Теорія і методика професійної освіти». Кропивницький. 2018. $327 \mathrm{c}$.

5. Равен Дж. Педагогическое тестирование: проблемы, заблуждения, перспективы. Москва: «Когито-Центр», 1999. 144 с.

6. Adabaş A., Kaygin H. Lifelong Learning Key Competence Levels of Graduate Students. Universal Journal of Educational Research, 2016, 4(12A), 31-38. DOI: 10.13189/ujer.2016.041305.

7. Annex «Key competences for lifelong learning a European reference framework». URL: https://eur-lex.europa.eu/legalcontent/EN/TXT/PDF/?uri=CELEX:32018H0604(01)\&from=EN

8. Dong Xiaobo. Cultural differences and cultivation of cross-cultural communicative competence in chinese FLT. International Education Studies. 2009. 2(2). 22-25. URL: http://files.eric.ed.gov/fulltext/EJ1065660.pdf.

9. Key competences for lifelong learning. Luxembourg: Publications Office of the European Union, 2019. 20 p.

10. Sicherl-Kafol, B. \& Denac, G. Through Musical Communication to Development of Competence in Culture Awareness and Expression. US-China Education Review, 2011, 8 (2), 129-136. 


\section{References}

1. Dubaseniuk, O. (2013). General cultural competence: essence and scientific approaches // Formation of general cultural competence of future specialists / Ed. O.S. Березюк, O.M. Vlasenko. Zhytomyr: I. Franko ZhSU Publishing House. 5-10.

2. Zyazyun, I. (2008). Philosophy of pedagogical action: monograph. Cherkasy: Bohdan Khmelnytsky National University. 608 p.

3. Korobova, I. (2016). Competence-oriented methodical training of future physics teachers on the basis of individual approach: monograph. Kherson: FOP Hrin' D. S. 366 p.

4. Protsenko, A. (2018). Formation of professional competence of future teachers of physical culture in the course of pedagogical practice: the dissertation of the candidate of pedagogical sciences: 13.00.04. Kropyvnytskyi. 327 p.

5. Raven, J. (1999). Pedagogical testing: problems, delusions, perspectives. Moscow: "Kogito-Center". 144 p.

6. Adabaş A., Kaygin H. (2016). Lifelong Learning Key Competence Levels of Graduate Students. Universal Journal of Educational Research, 4(12A), 31 - 38. DOI: 10.13189/ujer.2016.041305.

7. Annex «Key competences for lifelong learning a European reference framework». URL: https://eur-lex.europa.eu/legalcontent/EN/TXT/PDF/?uri=CELEX:32018H0604(01)\&from=EN

8. Dong Xiaobo (2009). Cultural differences and cultivation of cross-cultural communicative competence in chinese FLT. International Education Studies, 2(2). 22-25. URL: http://files.eric.ed.gov/fulltext/EJ1065660.pdf.

9. Key competences for lifelong learning (2019). Luxembourg: Publications Office of the European Union, $20 \mathrm{p}$.

10. Sicherl-Kafol, B. \& Denac, G. (2011). Through Musical Communication to Development of Competence in Culture Awareness and Expression. US-China Education Review, 8 (2), 129-136. 